\title{
PeAs in A Pod? CoMparing THE U.S. AND DANISH Mortgage Finance Systems
}

\author{
Jesper Berg, Morten Baekmand Nielsen, and James Vickery
}

\section{OVERVIEW}

- As it weighs mortgage finance reform, the United States can draw lessons from Denmark, whose system is similar in some key respects to that of the United States but enabled Denmark to better weather the crisis.

- The U.S. and Danish mortgage finance models both rely heavily on capital markets to fund residential mortgages, transferring interest rate and prepayment risk, but not credit risk, to investors. But in Denmark, homeowners can buy back their mortgages or transfer them in a property sale, avoiding the "lock-in" effects present in the U.S. system, and easier refinancing reduces defaults and speeds the transmission of lower interest rates in a downturn. Denmark's tighter underwriting standards and strong creditor protections help limit credit losses, while its higher capital requirements make lenders more stable.

- The Danish example suggests that a stable mortgage finance system is possible with a capital-markets-centric funding model, and without requiring a large role for government.
7 he way mortgages are designed, financed, and regulated varies strikingly across countries. ${ }^{1}$ Although this variation reflects adaptation to international differences in social, economic, and legal conditions, it likely also stems from historical accidents and path dependence. As the United States considers further reform of its mortgage finance system, it is useful to examine what can be learned from the experiences of other countries and whether any international practices could be adapted to improve the institutional design of the U.S. mortgage market.

With that goal in mind, this article compares and contrasts the U.S. system with that of Denmark. The Danish mortgage finance system is a salient reference point because, in several respects, it is the international model most similar to the U.S. system. In particular, Denmark relies very heavily on capital markets for funding residential mortgages, transferring interest rate risk and prepayment risk to fixed-income investors in a way that is similar to U.S. mortgage securitization. Unlike the U.S. system, however, the Danish mortgage finance system remained stable and solvent during the 2007-09 financial crisis and did not require government funding or

Jesper Berg is director of the Danish Financial Supervisory Authority, Morten Baekmand Nielsen head of Investor Relations at Nykredit Realkredit A/S, and James Vickery an assistant vice president at the Federal Reserve Bank of New York. Email: jb@ftnet.dk; mobn@nykredit.dk; james.vickery@ny.frb.org.

The views expressed in this article are those of the authors and do not necessarily reflect the position of the Danish Financial Supervisory Authority, Nykredit, the Federal Reserve Bank of New York, or the Federal Reserve System. To view the authors' disclosure statements, visit https://www.newyorkfed.org/research/epr/2018/epr_2018_US-danish-mortgage-finance_berg. 
capital injections, despite experiencing a fall in home prices of similar magnitude to that in the United States during this period.

In the Danish model, mortgages are financed through the issuance of "covered bonds" (bonds collateralized by a cover pool of mortgages or other debt) by a small number of specialized mortgage banks. The system relies on the "balance principle" - the covered bonds match the maturity and cash flows of the underlying pool of mortgages funded by the bond, and payments by mortgage borrowers are passed directly through to covered bond investors. Thus, interest rate risk and prepayment risk are borne by investors rather than by the mortgage bank that issues the covered bond. However, ownership of the mortgages is retained by the mortgage bank throughout its life, and the bank bears any credit losses on the mortgages.

This approach shares many similarities with the structure of the agency mortgage-backed securities (MBS) market in the United States, where mortgage bonds carry a credit guarantee from the Federal National Mortgage Association (Fannie Mae), the Federal Home Loan Mortgage Corporation (Freddie Mac), or the Government National Mortgage Association (Ginnie Mae). As in the Danish system, agency mortgages are funded by capital market investors who bear prepayment risk and interest rate risk but are not exposed to credit risk. Both agency MBS and Danish covered bonds are widely held and traded, and in both countries these bonds remained liquid throughout the 2007-09 crisis period and other market downturns (see Section 2 for more details).

This shared funding model explains why Denmark is also, to our knowledge, the only country aside from the United States where long-term (for example, thirty-year) prepayable fixed-rate mortgages (FRMs) are widely available to homeowners. Capital market financing is important for the availability of such loans because they embed significant interest rate and prepayment risk, which makes them less well suited for short-term bank deposit finance. Given the popularity and familiarity of FRMs in the United States, Denmark provides a useful case study because Danish homeowners ${ }^{2}$ have historically shared this same preference for FRMs. The Danish model may suggest ways to improve the efficiency of the U.S. mortgage finance system without restricting the types of contracts available to borrowers.

As we will describe, the Danish system includes several features that mitigate frictions in mortgage financing and could potentially be usefully adapted in some form in the United States. Prominent among these is the option for Danish homeowners to repurchase their own mortgages from the covered bond pool at the current market price. Mortgages are also assumable, meaning that a homeowner can transfer his or her mortgage to a buyer as part of a property sale. These features are useful in an environment of rising interest rates, since they reduce the tendency for the homeowner to become "locked in" to a mortgage with a below-market interest rate. Such lock-in can have perverse effects-for instance, it can discourage homeowners from selling their homes and moving (Quigley 1987; Ferreira, Gyourko, and Tracy 2010). The Danish system also allows homeowners to refinance easily at par with the same mortgage bank even if their home equity has declined because of a fall in home prices. Historically, this option has generally not been available in the United States, blunting the transmission of lower long-term interest rates to households during the recent recession (Beraja et al. 2017). However, recent policy changes are likely to make the U.S. system more similar to Denmark's in the future. ${ }^{3}$

Although we focus mainly on mortgage funding, we also compare the primary mortgage markets in Denmark and the United States. Here, the two systems are less similar. For instance, 
mortgages in Denmark generally have much less credit risk, and as a result Denmark experienced only a mild increase in credit losses during the financial crisis despite a sustained fall in home prices. This distinction reflects tighter underwriting standards (for example, minimum down payments of at least 20 percent are required on first-lien mortgages $\left.{ }^{4}\right)$, as well as a creditor-friendly legal system in which foreclosure is uniformly quick and lenders have full recourse against the borrower's assets and future income. In that sense, Danish mortgages embed less implicit insurance than U.S. mortgages, although that approach is partly made possible by the extensive social safety net offered in Denmark.

After comparing the Danish and U.S. systems, we highlight some lessons from the Danish experience that may be of interest in thinking about the future of U.S. housing finance. Among these: First, the Danish experience suggests that returning to a balance-sheet funding model is not necessary to ensure the stability of the U.S. mortgage finance system; Denmark has a capital-markets-centric system that, to date, has been stable and robust, without reliance on government support or bailouts. Second, it is possible within a framework similar to agency securitization to offer innovations that mitigate frictions in mortgage refinancing. Third, capital adequacy is critical for system stability. A key reason why Danish mortgage banks, unlike Fannie Mae and Freddie Mac, did not require government assistance during the financial crisis is that they were significantly better capitalized relative to the level of risk they assumed.

This article is related to a number of studies that discuss key features of the Danish mortgage finance system (Berg and Nielsen 2014; Campbell 2013; Green and Wachter 2005; Frankel et al. 2004). Aside from some differences in emphasis, our main contribution relative to this previous work is to present an up-to-date comparative analysis of the Danish and U.S. systems, taking into account the experiences of both countries during and since the financial crisis.

Section 1 provides a history and overview of the Danish model of mortgage finance. In Section 2, we compare the two systems side-by-side, examining both the way mortgages are funded and the features of the primary mortgage markets. Section 3 discusses possible lessons from the Danish experience for the path of future U.S. housing finance reform. Section 4 presents our conclusions.

\section{Overview of the Danish Approach to Mortgage Finance}

In Denmark, mortgage lending has long been dominated by specialized mortgage banks. Denmark's first mortgage bank was established in 1797, and Nykredit, the country's largest mortgage bank today, traces its origins to 1851 (Møller and Nielsen 1997). Originally, these firms were set up as mutual mortgage credit associations with a local focus. But several waves of mergers-some encouraged or even prescribed by their then-regulator ${ }^{5}$-led to the formation of the handful of large mortgage banks that today dominate mortgage lending in Denmark.

Because the original mortgage credit associations were founded by borrowers, lending terms were to a large extent designed to reflect borrowers' objectives and interests. At the same time, the associations needed to build trust among the investors in covered bonds, and this led 
to a business model aimed at balancing borrower and investor interests (Møller and Nielsen 1997). Key aspects of this business model included:

- Mortgage lenders could not call for early redemption of a loan unless the borrower became delinquent.

- Investors could not call the covered bonds.

- Homeowners had a right to prepay the mortgage loan at par on any payment day without penalty.

- Homeowners were personally liable for the mortgage debt.

- Homeowners were jointly and severally liable for the covered bonds issued by the mortgage credit association.

- Mortgage margins could be increased for the entire stock of mortgage loans-for example, if needed in order to increase capitalization or cover loan losses.

- Strict lending guidelines were instituted that were regulated by law (maximum LTV ratio, maximum maturity, and so forth). ${ }^{6}$

With the exception of joint and several liability, these principles still apply to mortgage banks today. ${ }^{7}$ However, the mid-1990s saw the beginnings of a shift in organizational form from mutual associations to limited liability corporations. The mortgage credit associations were first converted into limited liability companies owned by mutual associations, and later many were merged with banks to form financial conglomerates. ${ }^{8}$

Capital market funding has been a mainstay of the Danish mortgage financing system since the beginning in 1797 (Møller and Nielsen 1997). Inspired by the German and Austrian models, Denmark enacted its first Mortgage Credit Act in 1850, requiring the specialized mortgage credit associations to issue covered bonds to fund all mortgage lending, and prohibiting them from taking deposits. The ban on deposits stemmed from regulators' desire to eliminate any risk of a run on the lenders, who carried only long-term and illiquid mortgage assets on their balance sheets.

The specialized nature of mortgage bank assets and mortgage banks' reliance on covered bonds rather than deposits remain the key distinguishing features of Danish mortgage banks today. Danish mortgage banks can be viewed as a form of "narrow banking" - they do not engage in maturity transformation, since payments to covered bond investors match the cash flows of the underlying mortgages. Because they do not rely on deposits for funding, mortgage banks do not benefit from any implicit subsidies arising from deposit guarantees and structural subordination of covered bond investors relative to other creditors (the latter could be the case in a situation where deposit-taking banks issue covered bonds).

The covered bond structure provides a funding instrument with very low credit risk to investors, facilitating efficient funding of low-risk financial assets such as residential mortgages. For more background on covered bonds, see Box 1. 
Box 1

\section{The Basics of Covered Bonds}

Covered bonds are debt instruments issued by credit institutions financing a pool of segregated, or "ring-fenced," assets. Several different legal models are used for covered bonds in Europe. In Denmark, most covered bonds are issued by specialist mortgage banks that keep the mortgages on their balance sheets. Covered bonds issued in the European Union comply with special legislation from the European Union as well as national covered bond legislation. ${ }^{2}$

Covered bonds primarily fund mortgage lending, but they can also fund other types of assets (for example, public sector lending, ships, and infrastructure). These nonmortgage covered bonds are outside the scope of this article. ${ }^{\mathrm{a}}$

Unlike balance-sheet securitization, covered bonds offer the investor double recourse: exclusive recourse to the segregated pool of assets on the issuer's balance sheet, and (nonexclusive) recourse to the overall assets of the issuer. In order to ensure that the "cover pool" (in other words, the assets financed by the covered bonds) is of high quality, mortgage loans in the pool must comply with several requirements regulated by law regarding property types, maximum LTV ratios, substitute assets, and transparency.

The distinguishing feature of Danish covered bonds is that interest rate risk and prepayment risk are fully passed through to capital market investors under the balance principle. In other European Union countries, these risks are at least partially retained by the covered bond issuer.

The three largest covered bond markets in the world are Denmark, Germany, and France, as shown in the chart below. The United States does not have a significant covered bond market, in part

\section{Outstanding Covered Bonds, 2016}

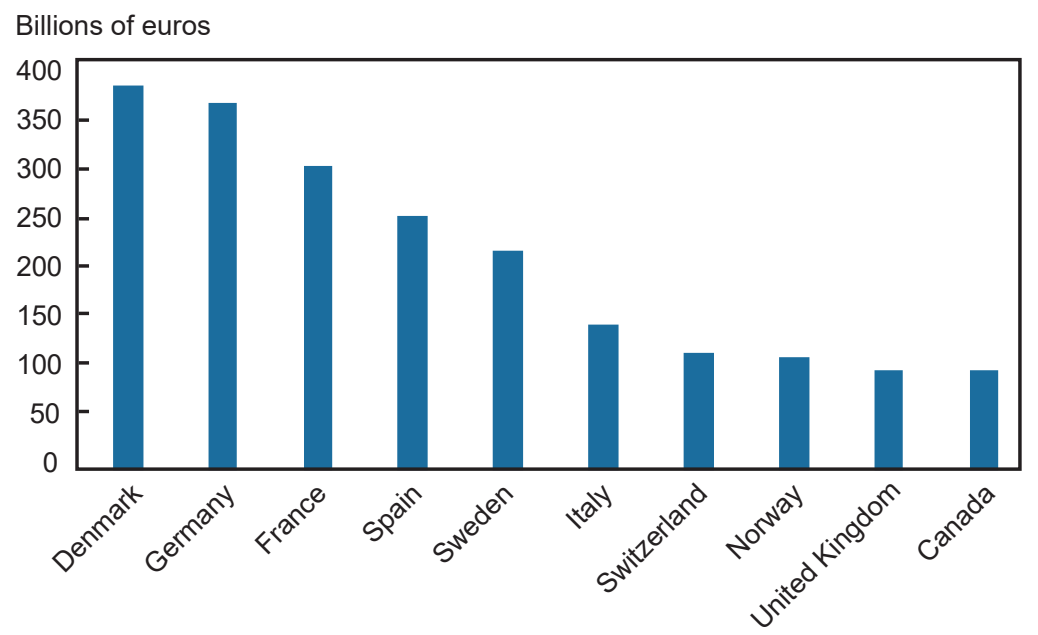

Source: ECBC European Covered Bond Fact Book, 2017.

Notes: Statistics in the chart cover all types of covered bonds backed by mortgages or public sector assets, for major European markets and Canada. Data are as of year-end 2016. 
Box 1 (CONTINUED)

because lenders have access to funding collateralized by mortgages through the Federal Home Loan Bank System (Bernanke 2009). ${ }^{\text {b }}$

${ }^{a}$ For more information on covered bonds, see European Covered Bond Council, https://hypo.org/ecbc/ covered-bonds/\#introducing-covered-bonds.

${ }^{\mathrm{b}}$ See Ashcraft, Bech, and Frame (2010) for more detail on the structure of the Federal Home Loan Bank (FHLB) System and the role of FHLB advances as a stable source of funding during the 2007-09 financial crisis. Like Fannie Mae and Freddie Mac, the FHLBs are government-sponsored enterprises (GSEs) created by an act of Congress. See Meuli, Nellen, and Nitschka (2017) for a discussion of the Swiss Pfandbrief covered bond instrument, which shares a number of similarities with the FHLB system.

\subsection{The Mortgage Origination Process}

As in the United States, the traditional mortgage contract in Denmark is a fixed-rate mortgage that fully amortizes over thirty years and may be prepaid at any time without penalty. A number of new types of loans have been introduced in Denmark over the past two decades, the most popular of which are adjustable-rate mortgages (ARMs) and interest-only loans. ${ }^{9}$ However, the growth in alternative mortgages has stopped short of the riskiest contract features seen in the United States prior to the financial crisis (for example, there are no negative amortization mortgages or no-documentation loans).

The homeowner's interest rate is directly linked to the lender's cost of funds. Specifically, the rate is equal to the current market yield of the "on-the-run" (in other words, most recently issued) covered bond in the capital market, plus a margin set by the lender. The bank simply acts as an intermediary between the borrower and the capital market. In principle, when a homeowner enters into a new mortgage, the mortgage bank provides her with covered bonds matching the principal amount being borrowed, which the borrower can then sell on the bond market. In practice, the mortgage bank will generally handle the sale of the bonds for a fee, and simply transfer the net proceeds of the bond sale to the homeowner's bank account. The mortgage bank pools thousands of loans with similar coupons and maturities to allow the buildup of large and liquid covered bond issues.

Danish mortgage banks have a vertically integrated business model—the same bank originates and owns the mortgages, funds them in the covered bond market, services the mortgages, and undertakes foreclosure proceedings if needed. In the United States, these different roles are often played by different financial institutions (for example, mortgages are often sold after origination, and many loans are serviced by a third-party servicer).

\subsection{Covered Bond Design and the Balance Principle}

Covered bonds are issued at coupon rates in 50 basis point increments, and each covered bond security is generally on the run for three years. This means that mortgages are progressively added to the cover pool for the bond over a three-year period, before the pool is closed. Because the market price of the bond fluctuates daily during the three-year on-the-run period, the 
Box 2

\section{The Mechanics of Issuing Bonds under the Balance Principle}

Mortgage banks keep bond series (each with a specific international securities identification number, or ISIN) on the run for three years and tap them on a daily basis to fund new lending. When a new bond series is started, it has thirty-three years to maturity. This interval allows the bank to fund loans with the maximum legal loan term of thirty years until the bond goes off the run. No loan in the cover pool backing the bond series will have a maturity in excess of thirty years, but since the loan portfolio is constructed over time, the amortization profile of the bond will reflect the gradual buildup of the underlying cover pool. The long three-year on-the-run period makes it possible to build up large and liquid series of covered bonds.

Under the balance principle, the amount lent to the homeowner exactly matches the net amount raised by selling covered bonds in the capital market. Bond market funding for each loan is obtained on the day the loan is disbursed, thus avoiding any pipeline risk for the bank.

The effective mortgage rate paid by the borrower will reflect the yield on the corresponding covered bond. Since bond prices fluctuate over time, different homeowners may have different yields-to-maturity despite being funded in the same bond series with the same coupon. Mechanically, this variation is achieved by adjusting the principal on the mortgage in a manner analogous to the U.S. practice of paying mortgage points. The following example illustrates the mechanics (for the sake of simplicity we exclude all fees and so forth):

A homeowner needs 1 million Danish kroner (kr.1 million) to purchase a house.

The on-the-run 2 percent thirty-year fixed-rate-mortgage bond trades at 99.00. The bank will then make a loan offer with a principal of $1 / 0.99=\mathrm{kr} .1 .01$ million. The homeowner is liable for the bond amount issued and will receive the proceeds of $\mathrm{kr} .1$ million. The quarterly interest payment will be 2 percent $/ 4^{\star} \mathrm{kr} .1 .01$ million, and hence, the homeowner's effective loan rate will be slightly above the 2 percent coupon of the bond, reflecting the fact that the 2 percent bond is trading at a discount.

Another homeowner taking out a loan the following day when the same bond series trades at 99.25 will be liable for a slightly smaller bond principal and pay a marginally lower effective interest rate.

Coupon rates are set at increments of 50 basis points. At the time of this writing, the Danish mortgage banks had bonds open for issuance with final maturity on October 1, 2050, with coupons of 1.5 percent, 2.0 percent, and 2.5 percent. Each homeowner will have her loan funded in the bond trading closest to par, thereby minimizing the number of points paid. If long-term interest rates, for instance, increase, mortgage banks will open new on-the-run bonds with higher coupons and start tapping them instead of the bonds with coupons below market rates. The end-date for the on-the-run period will be the same for all bonds of the same "vintage," irrespective of when in the three-year period they begin to be on the run.

homeowner's interest rate is set in a manner similar to the system known in the United States as paying points (see Box 2 for more details on the mechanics).

The funds received by the homeowner match the net amount raised from selling the corresponding covered bonds in the capital markets. Furthermore, on a flow basis, the cash flows received by covered bond investors exactly match the cash flows from the underlying pool of 
mortgages (except for a margin that is retained by the lender). Hence, if a mortgage has a refinancing option, the bond has a similar option. As mentioned earlier, this complete pass-through funding model is known as the balance principle.

The homeowner's quarterly mortgage payment equals the cash flow on the bonds issued to fund her loan plus a fixed margin to the mortgage bank. Thus, there is little market risk to the mortgage bank. However, the mortgage bank lender is exposed to credit risk, since the loan remains on its balance sheet until maturity. If the borrower becomes delinquent, the mortgage bank will use its capital buffers to repay the holders of covered bonds and will start foreclosure proceedings against the homeowner. In practice, however, mortgage credit losses in Denmark have historically been low, even during significant housing market downturns (see Section 1.4 for a more detailed discussion).

Unlike an "originate to distribute" approach, the retention of credit risk by the originator creates skin in the game and reduces information asymmetries, which together may contribute to the low mortgage default rates observed in Denmark. ${ }^{10}$ The market risk is less subject to asymmetric information and therefore easier to distribute to capital market investors.

This allocation of market and credit risk means that the mortgage bank has an incentive to refinance the loans of existing borrowers. Refinancing a mortgage at par to a lower interest rate reduces credit risk because it lowers the borrower's interest payments; while there is a loss in the market value of the loan because of the refinancing at par, this loss is borne by the covered bond investor owing to the balance principle. Since the original lender is responsible for loan servicing, there is also no disincentive to refinance associated with a loss of servicing fees.

\subsection{Refinancing and Prepayment}

Mortgage refinancing is an integrated process in which a borrower simultaneously takes out a new loan and uses the proceeds to repay the old loan. If the interest rate on the new mortgage is below that of the original loan, the repayment of the loan is at par. The homeowner will call the mortgage, and the mortgage bank will call a corresponding amount of the outstanding bonds at par at the same time. The mortgage bank will only call bonds corresponding to the actual mortgages that are being prepaid and thus does not take on any interest rate risk or prepayment risk.

In contrast, if the market interest rate exceeds the original loan rate, it is possible to prepay the loan below par. In this case, the mortgage bank will repurchase, at the current market price, the bonds backed by the homeowner's mortgage in the market, and then retire them. These bonds will be trading at a discount, given that market interest rates have increased since the old mortgage was originated. Thus, when the homeowner refinances, her new mortgage will have a smaller principal (since the old loan was redeemed at below par value) but a higher loan rate. Generally, these two effects will roughly offset each other, implying little net change in the borrower's mortgage payments. ${ }^{11}$ Danish mortgages are also assumable, which means it is possible for the homeowner to transfer her mortgage to a buyer as part of a property sale. This, in effect, is an alternative way for homeowners to "buy back" their mortgages.

This ability of Danish borrowers to repurchase their own loans at the market price has potentially important advantages in a rising interest rate environment (as emphasized by Campbell 2013). In the U.S. system, where FRM prepayment only occurs at par and the mortgage 
is generally due upon sale of the home, homeowners with a below-market mortgage interest rate face a "lock-in" effect: they have disincentives to move to a new home or change their loan terms (for example, from an FRM to an ARM, or to a loan with a different maturity), because doing so means they will have to retire their below-market-rate mortgage and take out a new loan at the higher current rate. This lock-in effect could generate allocative inefficiencies; for example, it may reduce housing market turnover and limit homeowners' ability to adjust their consumption of housing services in response to changes in economic circumstances. Ferreira, Gyourko, and Tracy (2010) and Quigley (1987) present empirical evidence that mortgage rate lock-in reduces household mobility in the United States. The lock-in effect is not present in Denmark, given that the cost of refinancing to a new, higher interest rate is offset by the capital gain from repurchasing the old mortgage below par.

An additional implication of borrowers' ability to repurchase their loans from the cover pool is that homeowners can act as a source of liquidity in the covered bond market. When interest rates increase and liquidity in the market for existing bonds typically suffers, refinancing activity adds to the demand for bonds for redemption. Homeowners can also act as "buyers of last resort" in situations where covered bond prices become too low relative to fundamentals.

Streamlined mortgage refinancing is available to Danish homeowners who refinance their mortgage with the same lender, as long as the homeowner does not want to extend the term of the loan or extract equity from the home by increasing the mortgage principal amount. ${ }^{12} \mathrm{~A}$ property appraisal is not needed, and the borrower is not required to provide updated documentation of income or assets. Streamlined refinancing is permitted even if home prices have fallen and the homeowner's updated LTV ratio has risen beyond the statutory maximum of 80 percent for purchase mortgages. ${ }^{13}$ As noted earlier, the logic behind this "no questions asked" approach is that re-underwriting the loan is not necessary because the lender already bears the credit risk on the mortgage. In fact, allowing the borrower to refinance to a lower market interest rate actually reduces the lender's credit risk exposure because it reduces the homeowner's debt payments.

The availability of streamlined refinancing makes it easier for borrowers to refinance during periods of depressed home prices. This contract feature could have been of significant value in the United States in the wake of the 2008 financial crisis (see Section 2.3 for further discussion).

\subsection{Credit Risk and Foreclosure}

Realized mortgage credit losses in Denmark have been low over a long period of time. Historical credit loss rates on mortgages and other loans back to the early twentieth century are plotted in Chart 1. Over that period, credit losses for Danish mortgage banks have averaged about 10 basis points per annum and have consistently been much lower and less volatile than losses on nonmortgage loans held by deposit-taking banks. Even during the 2007-09 financial crisis, the mortgage credit loss rate topped out at only around 20 basis points. The peak mortgage credit loss rate for the full period was realized during the Scandinavian banking crisis in the early 1990s, although this peak was driven in part by a change in accounting standards to a more forward-looking method for calculating provisions.

The low credit losses experienced by Danish mortgage banks are not simply the result of a lack of economic volatility. The drop in Danish house prices during the financial crisis was on 


\section{Chart 1}

Credit Loss Rates on Danish Covered Bond Assets and Bank Loans

Loan Impairments as a Percentage of Loans and Guarantees

- Banks — Mortgage banks

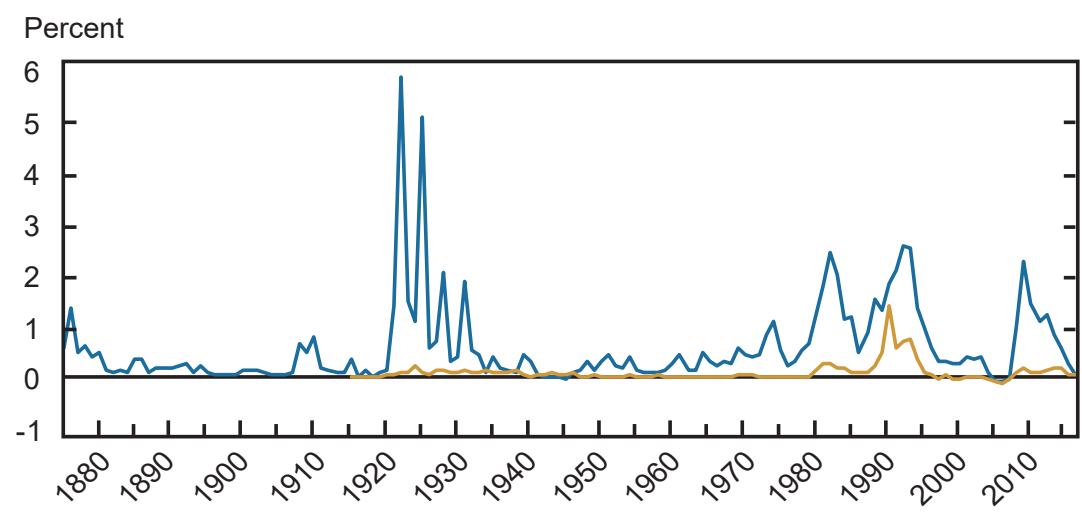

Source: Danmarks Nationalbank.

Note: The chart shows annual credit loss rates for mortgage banks and deposit banks.

par with the fall in U.S. house prices (Berg and Nielsen 2014), and in an International Monetary Fund (2000) study, the Danish housing market was characterized as the most volatile in the western world over the post-Bretton Woods era. ${ }^{14}$ Denmark has also experienced significant business cycle fluctuations, as reflected in the high and variable loss rates on nonmortgage loans in Chart $1 .^{15}$

Instead, low mortgage credit loss rates primarily reflect limits on up-front loan-to-value ratios, as well as strong creditor protections in Denmark, as in other countries with a German or Scandinavian legal tradition (Djankov, McLeish, and Shleifer 2007). Most important among these protections, the homeowner is personally liable for her mortgage loan; thus, the lender is protected both by the value of the collateral and the payment capacity of the homeowner. Control rights are also strongly enforceable; in Denmark, a foreclosure is typically completed six to nine months from the time the homeowner misses a payment. Even after a foreclosure is completed, the borrower remains liable for any debt that remains unpaid. These factors discourage mortgage delinquency and generally ensure that "loss given default" - the amount of money the bank loses when a borrower defaults-is low.

The creditor-friendliness of the Danish system in turn means that relatively more price risk is borne by the homeowner. However, this risk is offset by an extensive social safety net, including a city obligation to provide rental housing to homeowners displaced by foreclosure. In this sense, some features of the Danish mortgage system reflect broader societal choices about social insurance and the role of government. Although these choices differ between Denmark and the United States, there are a number of close parallels in mortgage funding arrangements between the two countries, as we now explain. 


\section{Comparing the Danish Model to the U.S. Model}

Table 1 compares the key features of the Danish mortgage finance system with those of the U.S. system, focusing on secondary mortgage markets. Although nearly all Danish mortgages are financed through covered bonds, the United States has a more heterogeneous system that makes use of a mix of three main funding sources:

1. Agency securitization, in which the resulting mortgage-backed securities have a credit guarantee from one of the housing government-sponsored enterprises (GSEs) Fannie Mae or Freddie Mac or from the government agency Ginnie Mae.

2. Non-agency securitization, in which MBS are securitized by an investment bank or other private sector firm.

3. Balance-sheet lending, in which the mortgage is kept in portfolio as a whole loan by the originator, or sometimes by another investor (for example, a large bank that purchases the loan from a correspondent lender, or a real estate investment trust). Most balance-sheet loans are owned by commercial banks and funded by a mix of deposits and advances from the FHLB system.

Of these three approaches, agency securitization is the one most similar to the Danish covered bond model. In both cases, mortgages are ultimately financed by the issuance of mortgage bonds that transfer interest rate risk and prepayment risk-but not credit risk-to capital market investors. In Denmark, credit risk is borne by the covered bond issuer, who retains ownership of the mortgages; this guarantee is credible because mortgages themselves have low credit risk and because mortgage banks are well capitalized. In the United States, a credit guarantee is provided to MBS investors by Fannie Mae, Freddie Mac, or Ginnie Mae. These guarantees are credible because Ginnie Mae is a government agency and Fannie Mae and Freddie Mac are viewed as being backed by an implicit federal government guarantee.

Like the Danish mortgage banks, Fannie Mae and Freddie Mac are specialized financial institutions focused on the mortgage market. Unlike Danish mortgage banks, however, Fannie Mae and Freddie Mac are not mortgage lenders; they operate only in the secondary mortgage market, purchasing loans from banks and other mortgage originators and assembling them into MBS pools. Thus, the intermediation chain is at least one step longer in the U.S. agency mortgage market than in Denmark. ${ }^{16}$

The Danish model has less in common with non-agency securitization and balance-sheet lending. Unlike the case with covered bonds or agency MBS, non-agency MBS investors are directly exposed to credit risk. Subordination and other forms of credit enhancement are used to mitigate this risk and redistribute it across investors. The non-agency MBS market is also traditionally less standardized than the agency market, with a much larger number of issuers and greater variation in security design. Non-agency securitization, while very popular in the period before the 2007-09 financial crisis, has not been a major source of mortgage funding since the crisis. Still, non-agency securitization represents the use of capital markets to fund residential mortgages, in common with the Danish model.

In the case of balance-sheet lending, however, the lender does not make use of capital markets; instead, the mortgage is retained in the portfolio of a financial intermediary, usually a 
TABLE 1

Mortgage Funding in Denmark and the United States

United States

\begin{tabular}{|c|c|c|c|c|}
\hline & Denmark & $\begin{array}{c}\text { Agency } \\
\text { Securitization }\end{array}$ & $\begin{array}{l}\text { Non-agency } \\
\text { Securitization }\end{array}$ & $\begin{array}{l}\text { Balance-Sheet } \\
\text { Lending }\end{array}$ \\
\hline How are loans funded? & $\begin{array}{l}\text { Capital } \\
\text { markets }\end{array}$ & $\begin{array}{l}\text { Capital } \\
\text { markets }\end{array}$ & $\begin{array}{l}\text { Capital } \\
\text { markets }\end{array}$ & $\begin{array}{c}\text { Deposits or } \\
\text { FHLB advances }\end{array}$ \\
\hline Capital markets instrument & Covered bonds & Agency MBS & $\begin{array}{l}\text { Non-agency } \\
\text { MBS }\end{array}$ & N.A. \\
\hline Originator retains the credit risk? & Yes & No & No & Usually \\
\hline $\begin{array}{l}\text { Borrower can repurchase mortgage } \\
\text { from secondary market pool? }\end{array}$ & Yes & No & No & N.A. \\
\hline \multicolumn{5}{|l|}{ Who bears: } \\
\hline Interest rate risk? & Investor & Investor & Investor & Bank \\
\hline Prepayment risk? & Investor & Investor & Investor & Bank \\
\hline Credit risk? & Mortgage bank & $\begin{array}{l}\text { Fannie Mae, } \\
\text { Freddie Mac, or } \\
\text { U.S. government }\end{array}$ & Investor & Bank \\
\hline
\end{tabular}

Notes: FHLB is Federal Home Loan Bank; MBS is mortgage-backed securities.

commercial bank. The marginal source of financing for such loans includes deposits and FHLB advances. This more traditional approach aligns incentives but does not allow for the transfer of any of the major types of risk associated with mortgage lending.

\subsection{Mortgage Bond Secondary Market Liquidity}

As we have noted, a key feature shared by the U.S. agency MBS market and the Danish covered bond market is that mortgage bonds have little or no credit risk to the investor. This feature allowed both markets to remain active throughout the period of the financial crisis and afterward, as illustrated in Chart 2. Although spreads on Danish mortgage bonds were elevated during the crisis, the market continued to operate and to intermediate mortgage credit. Similarly, primary market issuance and secondary market trading remained robust for agency MBS, despite the collapse in home prices and the financial distress experienced by Fannie Mae and Freddie Mac. In contrast, the U.S. non-agency MBS market was not robust during the crisis period: Issuance froze in the second half of 2007 and the market was closed as a source of funding for mortgage originators throughout the crisis period. 


\section{Chart 2}

Mortgage Bond Liquidity during the Crisis

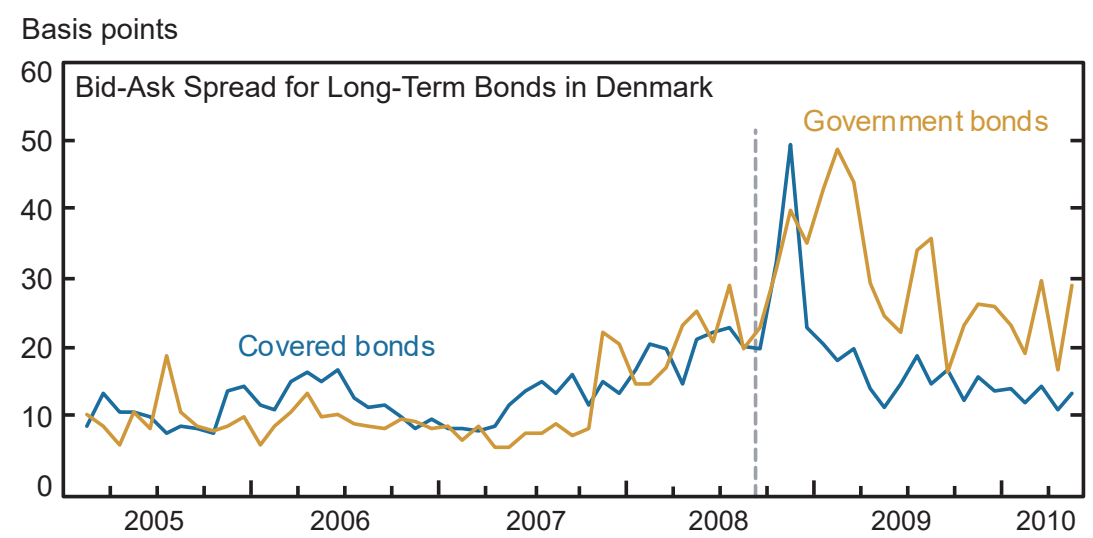

Daily average volume (billions of dollars)

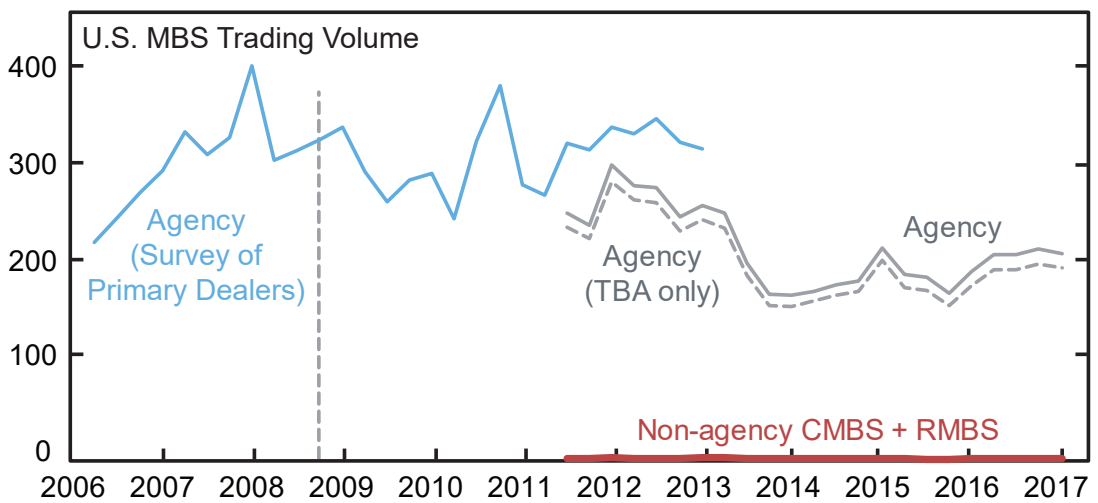

Sources: Nasdaq OMX; Danish Financial Supervisory Authority; Danmarks NationalBank; Securities Industry and Financial Markets Association (SIFMA). Drawn from SIFMA Trade Reporting and Compliance Engine (TRACE) data, unless otherwise noted.

Notes: In the top panel, only bonds with an outstanding nominal amount of at least $€ 1$ billion and trades of at least kr.10 million have been included. MBS is mortgage-backed securities; TBA is to-be-announced; CMBS is commercial mortgage-backed securities; RMBS is residential mortgage-backed securities. The vertical dashed lines mark the September 15, 2008, failure of Lehman Brothers.

In our view, the presence of a credible credit guarantee by the issuer is a key reason why both the agency MBS market and the Danish covered bond market remained relatively liquid and functioned relatively well during the crisis. The lack of credit risk on these instruments greatly reduces the adverse selection that arises from asymmetric information about mortgage credit risk, a factor that likely contributed to the freeze in non-agency MBS issuance in 2007. The credit guarantee also helps standardize mortgage bonds and is an important factor underlying the operation of the to-be-announced (TBA) market in the United States, where most secondary market trading of U.S. agency MBS occurs (Vickery and Wright 2013). 


\subsection{Mortgage Contract Design}

A comparison of mortgage contract design and other aspects of primary mortgage markets is presented in Table 2. As Green and Wachter (2005) and others have observed, a notable implication of the U.S. and Danish capital-markets-centric mortgage systems is that in both countries, mortgage intermediaries are willing to originate long-term fixed-rate mortgages (with a fixed rate for as long as thirty years) and to offer borrowers the option to freely prepay such mortgages at par.

Long-term, prepayable FRMs are not generally available outside of Denmark and the United States (Green and Wachter 2005; Campbell 2013). This distinction is likely owing, at least in part, to the duration mismatch between these instruments and deposit finance and other shorter-duration liabilities that are the usual sources of bank funding. Capital markets funding allows the interest rate risk and prepayment risk of FRMs to be shared with other types of fixed-income investors that have lower leverage, long investment horizons, or a less concentrated exposure to mortgages (for example, pension funds, life insurance companies, sovereign wealth funds, and other asset managers). Fuster and Vickery (2015) present empirical evidence that the availability of liquid securitization markets facilitates the availability of long-term, prepayable fixed-rate mortgages in the United States. ${ }^{17}$

In both countries, mortgages with variable interest rates are also available. In the United States, the most popular such mortgages are hybrid adjustable-rate mortgages (ARMs), where the rate is fixed for an initial time period (for example, five years) and then becomes a floating rate that adjusts periodically based on movements in market interest rates. In Denmark, as we noted in Section 1, adjustable-rate mortgages consist of a number of equally spaced, shorter fixed-rate periods (usually either three years or five years), between which the interest rate resets.

\subsection{Prepayment and Refinancing}

Although the United States and Denmark both rely heavily on long-term FRMs, some significant differences exist between the two countries in borrowers' ability to easily refinance or repurchase their mortgages. Notably, although both countries allow mortgages to be prepaid freely at par, the United States, unlike Denmark, does not allow homeowners to redeem their mortgages at the current market price by purchasing mortgage bonds and surrendering them to the lender (as described in Section 1.3). Furthermore, mortgages in the United States are usually not assumable, meaning that a homeowner cannot "sell" her mortgage to a buyer as part of a property sale. ${ }^{18}$ In Denmark, however, mortgages can uniformly be assumed as part of a property sale (on approval of the lender), and the practice is common.

As we have detailed, an implication of these features is that, in a rising rate environment, U.S. fixed-rate mortgage borrowers may find themselves locked into a loan with an interest rate below current market rates. Such borrowers would have a disincentive to sell their home and move, even if their current dwelling no longer best fit their economic circumstances. Borrowers also have a disincentive to refinance to a mortgage with different contract features or a higher principal balance because doing so would require them to prepay their below-market-rate loan and take out a new loan at the higher current rate. 
TABLE 2

Primary Mortgage Markets in Denmark and the United States

Denmark United States

Mortgage contract design

Long-term fixed-rate mortgages available?

Yes

Yes

Maximum fixed-rate term?

30 years

30 years

Mortgages prepayable on demand?

Yes

Yes

Mortgage is assumable in a property sale?

Yes

Usually not

Refinancing requires underwriting?

Not with same lender

Usually

Other mortgage types available?

ARMs, floating-rate, capped floating-rate

Hybrid ARMs, reverse mortgages, HELOCs

Default and underwriting standards

Recourse in case of default?

Maximum first-lien mortgage loan-to-value?

Role of government

Government provides mortgage insurance?

Mortgage interest is tax deductible?

Market size and structure

Mortgage debt outstanding (billions of dollars)

Concentration: market share of four largest

mortgage lenders
470

10,600

Full

Limited

$80 \%$

No

Yes

Yes

$100 \%$

97-100\%

Yes

Sources: Data sources for market size and structure: Federal Reserve Board, Financial Accounts of the United States; Bloomberg L.P.; Home Mortgage Disclosure Act data.

Notes: ARM is adjustable-rate mortgage; HELOC is home equity line of credit.

In addition, refinancing an existing mortgage at par has historically been a more streamlined process in Denmark than in the United States. As noted in Section 1.3, refinancing with the same mortgage bank in Denmark does not require a new credit check, proof of employment, or home appraisal, and homeowners can still freely refinance even if their home value has fallen and they have little or no remaining equity. A similar structure in the United States would likely have helped stabilize economic conditions during the Great Recession, when falling 
home prices and tighter underwriting standards meant that many borrowers could not refinance to take advantage of lower interest rates. Beraja et al. (2017) find evidence that these refinancing frictions blunted the transmission of lower interest rates to the real economy in regions hardest hit by the housing market decline. The Home Affordable Refinancing Program (HARP) was eventually introduced to facilitate refinancing for borrowers with little or no remaining home equity. Researchers have found that HARP significantly increased mortgage refinancing, leading to higher consumption of durable goods and reduced foreclosure rates (Agarwal et al. 2017).

Although HARP is scheduled to expire at the end of 2018, permanent post-crisis changes in refinancing rules should bring the U.S. system significantly closer to Denmark's in facilitating mortgage refinancing during periods of falling home prices. Specifically, Fannie Mae and Freddie Mac have announced that starting in late 2018 they will introduce permanent streamlined refinancing programs that will allow borrowers with high LTVs as a result of falling property prices to refinance using an automated appraisal and with no minimum credit score (Federal Housing Financing Agency 2017; Freddie Mac 2017). ${ }^{19}$ Some restrictions apply regarding the types of borrowers who will be able to participate. ${ }^{20}$ Prior research has noted that limited competition and other frictions reduced the effectiveness of the HARP program to some extent (Agarwal et al. 2017; Amromin and Kearns 2014). It will be interesting to assess the new streamlined refinancing programs in the wake of any future regional or national housing market downturns to confirm their effectiveness.

\subsection{Other Features of Primary Mortgage Markets}

Table 2 also highlights several starker differences between the two countries in the structure of primary mortgage markets. As we have noted, Danish mortgage contracts are very creditor-friendly and foreclosure is quick; this is not generally the case in the United States, although creditor rights vary significantly from state to state (Ghent and Kudlyak 2011). The U.S. mortgage market is much less concentrated, encompassing several thousand originators (compared with only four in Denmark), and it features competition between banks and nonbanks, with nonbanks currently originating about half of new loans. This dynamic of competition between banks and nonbanks may be one reason that U.S. lending standards have fluctuated over time. The United States is also, of course, a much larger market, given its greater population.

\section{What Can the United States Learn FROM THE DANISH EXPERIENCE?}

The Danish experience offers a number of lessons that may be of interest for U.S. policymakers in considering the path of housing finance reform. We summarize these lessons below.

A capital-markets-centric system doesn't necessarily imply instability. Criticism of the U.S. mortgage finance system often focuses on securitization and the system's reliance on capital markets. But Denmark's experience suggests that a stable and robust mortgage finance system is possible 
Chart 3

Capitalization of Danish Mortgage Credit Institutions, 2001-16

_ Capital as a percentage of risk-weighted assets

- Capital as a percentage of total assets

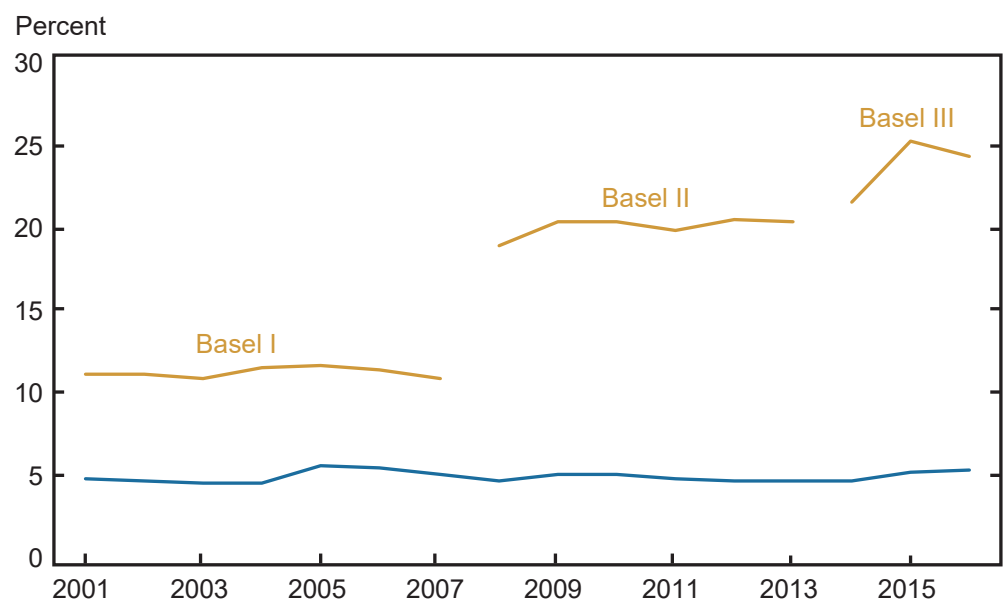

Source: Firm filings to the Danish Financial Supervisory Authority.

Notes: The chart is based on Basel I regulation 2001-07, Basel II regulation 2008-13, and Basel III regulation 2014-. Basel standards are transformed into European regulation and directives (CRR/CRD). Data are reported by institutions at a consolidated level.

even with a capital-markets-centric funding model and without requiring a large role for government. Returning to a bank-deposit-based funding model isn’t necessary to achieve stability for the U.S. mortgage finance system. In our view, a significant reduction in systemic risk is possible when capital markets are used to broaden the mortgage investor base and diversify the market risk of long-term fixed-rate mortgages. ${ }^{21}$

Mortgage intermediaries should be well-capitalized. Danish mortgage banks remained solvent throughout the financial crisis in part because they retain relatively little risk (credit risk is low, and Danish mortgage banks transfer essentially all market risk to investors under the balance principle). But Danish banks are also well-capitalized, with a risk-based capital ratio that has not fallen below 10 percent since 2001, and a leverage ratio of about 5 percent (see Chart 3 ). In contrast, Fannie Mae and Freddie Mac retained large portfolios of mortgage assets prior to their conservatorships and held only a thin layer of capital for the mortgages they guaranteed (the required capital ratio for securitized agency mortgages was only 0.45 percent). ${ }^{22}$ In any future reform of mortgage finance, limiting the role of implicit government guarantees in the mortgage finance system will only be possible if systemically important private sector mortgage intermediaries are financed with sufficient capital relative to their risks. 
Mortgage system design can help facilitate more efficient refinancing. As we have noted, the Danish system includes features that help facilitate efficient mortgage prepayment and refinancing. ${ }^{23}$ Danish homeowners are able to repurchase their mortgage out of a covered bond at the prevailing market price and to transfer a mortgage as part of a property sale. These features reduce mortgage lock-in effects during rising rate environments. Danish lenders also offer streamlined refinancing to homeowners even if home prices have fallen and the borrower's equity has declined or disappeared.

The centralized structure of the U.S. agency MBS market may offer opportunities to introduce these features in some form or to introduce other changes that could improve the efficiency of mortgage refinancing and facilitate interest-rate pass-through. ${ }^{24}$ Indeed, the permanent high-LTV refinancing programs being implemented by Fannie Mae and Freddie Mac are a step in this direction. Changes in ex ante mortgage design reduce the need for ex post government programs during periods of stress; such programs are difficult to design and scale up "on the fly" and take time to be implemented.

Credit guarantees on mortgage bonds support market functioning. The Danish covered bond market continued to operate and to intermediate mortgage credit during the 2007-09 financial crisis period, an outcome similar to that seen in the agency MBS market in the United States but unlike that in the U.S. non-agency market, which froze in 2007. The presence of a credible credit guarantee on the mortgage bonds was a key feature supporting market functioning in both the agency MBS and Danish covered bond markets during this period. This guarantee reduced adverse selection stemming from asymmetric information about mortgage credit risk (a factor that likely contributed to the freeze in non-agency MBS issuance in 2007) and helped standardize mortgage bonds, thereby supporting the operation of the TBA market in the United States, where most secondary market MBS trading occurs (Vickery and Wright 2013). In short, both the Danish and the U.S. experience suggest that a credible credit guarantee on mortgage bonds helps stabilize the supply of mortgage finance over the cycle and supports secondary market liquidity.

Government can play a smaller role. Government plays a much smaller role in the Danish mortgage finance system than in the U.S. system. For instance, Denmark does not have government mortgage insurance programs or hybrid private-public mortgage entities like the GSEs in the United States. This fact is particularly striking given that Denmark overall has a larger public sector and a greater role for government in economic life. Entanglements between the private and public sectors played a significant role in the instability of the U.S. mortgage market leading up to and during the financial crisis. For example, implicit government guarantees of the liabilities of Fannie Mae and Freddie Mac allowed the two firms to issue debt more cheaply than other private firms, fueling the growth in the GSEs' balance sheets and exacerbating their exposure to the housing downturn (Passmore 2005; Frame et al. 2015).

Given the size and systemic importance of housing and mortgage markets, the government is always likely to bear some tail risk exposure to the mortgage finance system. Even so, the Danish example shows that a system similar to the U.S. agency MBS market can operate with a significantly smaller role for government than is the case in the United States. A range of GSE reform proposals include ways to reduce the role of government in mortgage finance. For example, the credit risk transfer programs introduced by the GSEs provide a mechanism to shift mortgage credit risk to the private sector. 
The five discussion points highlighted above focus on secondary mortgage markets and funding arrangements, the areas where the Danish and U.S. mortgage systems are most similar. Other features of the mortgage markets differ more starkly, in part owing to broader differences in the design of social insurance and the role of government in the two countries. Denmark has a more extensive social safety net than the United States, although debt markets in the United States have more "insurance-like" features that allow non-repayment in response to negative shocks, through personal bankruptcy law and limits on mortgage recourse..$^{25}$ An evaluation of the broader trade-offs between these and other forms of private and social insurance is beyond the scope of this article, but the topic is studied in the public economics literature (for example, Hsu, Matsa, and Meltzer 2017; White 2007; Brown and Finkelstein 2008).

\section{Conclusion}

We have highlighted a number of similarities between the U.S. and Danish mortgage finance systems and offered a number of potential lessons from the Danish experience that may be of interest for U.S. policymakers in charting the course of mortgage finance reform. The Danish example shows that a capital-markets-centric model of mortgage finance does not necessarily imply structural instability or require a large role for government. The Danish model also offers a number of design features that could mitigate refinancing frictions and facilitate monetary policy transmission through the mortgage market during housing downturns. 


\section{Notes}

Acknowledgments: The authors thank Scott Frame and Joseph Tracy for helpful comments.

${ }^{1}$ See Campbell (2013), Lea (2010), and Green and Wachter (2005) for surveys and discussion of international variation in mortgage market design.

${ }^{2}$ In this article we generally restrict our attention to the residential mortgage market and refer to Danish borrowers as homeowners, even though Danish mortgage banks also finance commercial real estate and farms along the same principles as described here.

${ }^{3}$ The Home Affordable Refinancing Program (HARP) was introduced in the United States in the wake of the financial crisis to facilitate refinancing for borrowers with little or no remaining home equity. HARP is scheduled to expire at the end of 2018 but will be replaced by permanent high loan-to-value (LTV) streamlined refinancing programs offered by Fannie Mae and Freddie Mac. See Section 3 for a more detailed discussion.

${ }^{4}$ Danish commercial banks are willing to finance up to 15 percent of the remaining 20 percent, but this financing takes place outside the covered bond system. By comparison, in the United States, Federal Housing Administration (FHA) loans can have down payments as low as 3.5 percent. Fannie Mae and Freddie Mac also purchase loans with low down payments, although third-party credit enhancement is required for loans with LTV ratios exceeding 80 percent.

\footnotetext{
${ }^{5}$ Mortgage banks were originally regulated and supervised by the Danish Ministry of Housing. Today, the Ministry of Industry, Business, and Financial Affairs is the mortgage bank regulator, and the Danish Financial Supervisory Authority is the supervisor.
}

${ }^{6}$ Specifically, legislation in Denmark titled "Law on Mortgage Lending and Mortgage Bonds" includes restrictions such as an 80 percent maximum LTV, thirty-year maximum maturity, full amortization with a maximum initial interest-only period of ten years, a legal documentation requirement, and specific principles for assessing the value of a property.

${ }^{7}$ Although borrowers are no longer personally liable for the covered bonds, mortgage banks can still elect to increase margins on existing borrowers if needed to increase capitalization or cover loan losses. This option to adjust margins arises out of the original mutual structure of the mortgage banks. This feature implies that, contrary to U.S. practice, small interest rate changes are possible even for a fixed-rate mortgage. In practice, raising margins affects the lender's reputation and competitiveness, and since mortgage borrowers can easily move from one bank to another, the scope to raise margins is limited, unless there is a general increase in credit losses or funding costs that affects all banks at the same time. As a result, margins tend to fluctuate little and often remain constant for several years at a time. Over the past ten years, average mortgage margins have increased from approximately 50 basis points to just over 80 basis points.

${ }^{8}$ When Denmark implemented the Capital Requirement Directive in 2007, it also decided to allow deposit-taking banks to issue covered bonds. So far, only one bank has opted to issue covered bonds.

${ }^{9}$ Unlike U.S ARMs, which typically switch to a floating interest rate after an initial fixed-rate period, ARMs in Denmark consist of a number of equally spaced fixed-rate periods, most commonly either three years or five years. However, the borrower has the option to change the length of the fixed-rate period on each reset date. On each reset date, the new mortgage interest rate is based on bond market yields at the time the rate is fixed, removing any basis risk for the bond issuer. For interest-only mortgages, the initial interest-only period cannot exceed ten years.

${ }^{10}$ In the agency mortgage market in the United States, Fannie Mae and Freddie Mac retain mortgage credit risk in the same way as Danish mortgage banks, but Fannie and Freddie do not originate mortgages. Demiroglu and James (2012) find evidence that securitized mortgage losses in the United States were lower for securities in cases where the issuer was also the mortgage originator. See Willen (2014) for the case against mandatory mortgage risk retention. 


\title{
Notes (Continued)
}

\begin{abstract}
${ }^{11}$ For example, if mortgage rates increase by 200 basis points, our homeowner from the example in Box 2 will now see the bonds issued to fund her loan trading at, say, 85 cents to the dollar. Assuming that a new mortgage loan with a coupon of 4 percent could be disbursed at par value, the homeowner will need a new mortgage of just over kr.0.85 million to redeem her old loan. The homeowner will thus realize a capital gain of kr.0.15 million. However, her annual mortgage payment, including amortization, will remain broadly unchanged at approximately kr.38,000 after tax (taking into account a 32 percent tax rate deduction for interest payments) because the lower principal will be offset by a higher interest rate on the new loan.
\end{abstract}

${ }^{12}$ However, the homeowner is allowed to roll refinancing costs (for example, origination fees) into the refinancing, in which case the new principal will be slightly higher than the old principal.

${ }^{13}$ The updated LTV is estimated based on an automated valuation of the property, taking into account price appreciation or depreciation in the local geographic area. Homeowners with an updated LTV exceeding 80 percent face some restrictions on taking out an interest-only mortgage. Specifically, the lender must record a credit impairment charge if the borrower refinances to an interest-only loan. For this reason, some lenders will require the homeowner to refinance to an amortizing loan, even if the old mortgage is interest-only.

${ }^{14}$ One reason for this volatility is the pegging of the Danish currency to that of Germany and, subsequently, the euro zone. As a result, for the past thirty years, Danish monetary policy has focused on maintaining a fixed exchange rate rather than stabilizing the domestic economy.

${ }^{15}$ In recent decades, Denmark has experienced negative or zero annual GDP growth in 1974-75, 1980-81, 1988, 1991, 2008, and 2009.

${ }^{16}$ The U.S. primary mortgage market is much more fragmented than that of Denmark, encompassing thousands of individual small lenders, many of which are nonbanks. In practice, a Danish-style system in which all mortgage bonds are issued by the original lender does not seem possible under the current market structure in the United States.

${ }^{17}$ Fuster and Vickery (2015) find that the share of FRMs is significantly lower when mortgages are difficult to securitize. Shocks to MBS liquidity and cutoff rules governing which loans are eligible for agency purchase are found to be sources of variation in the ease of securitization.

${ }^{18}$ In general, conventional U.S. mortgages have a due-on-sale clause and are not assumable except in the case of the borrower's death. FHA and Veterans Administration (VA) mortgages may be assumed, subject to lender approval (see, for example, Guttentag [2010] for more details).

${ }^{19}$ The FHA and VA already offer streamlined refinancing programs that waive the requirement for an appraisal and require less verification of income, assets, or credit when refinancing to a lower interest rate.

${ }^{20}$ For example, the homeowner must be performing on her existing mortgage and have no recent delinquencies, the loan must be at least fifteen months old, and the LTV must exceed a minimum threshold ( 95 percent for a single-family owner-occupied home). HARP loans are also ineligible. See Freddie Mac (2017) for more details.

${ }^{21}$ The savings and loan crisis of the 1980s is a case study of the problems that can arise from funding long-term fixed-rate mortgages using bank deposits. See Kane (1989) and Barth (1991) for a detailed discussion of the crisis.

${ }^{22}$ Significant progress has been made since the financial crisis to reduce the risk footprint of the GSEs, for example by shrinking the size of the two firms' retained portfolios of mortgage assets and by using credit risk transfer instruments to hedge mortgage credit risk (see Finkelstein, Strzodka, and Vickery [2018], in this volume, for an overview of the credit risk transfer programs). However, the two GSEs today operate with essentially no equity capital and thus are entirely reliant on government support to cover any losses.

${ }^{23}$ It should be noted that such features are not a free lunch, in the sense that facilitating easier refinancing ex post will be "priced in" by MBS investors and therefore affect mortgage interest rates at origination. However, reducing these frictions would likely reduce distortions in other economic decisions (for example, decisions to move by otherwise locked-in borrowers) and could enhance the pass-through of monetary policy. 


\section{Notes (Continued)}

${ }^{24}$ For instance, Eberly and Krishnamurthy (2014) propose an "automatic stabilizer" mortgage that would convert into a lower adjustable interest rate during housing downturns. The GSEs could require that agency-eligible fixed-rate mortgages contain such a feature. More ambitious proposals to reduce refinancing frictions and transaction costs include fixed-rate mortgages with a "ratchet" feature, under which the interest rate adjusts downward automatically if market interest rates fall (Kalotay 2015). This type of automatic refinancing mortgage would address the fact that many mortgage borrowers do not refinance optimally, as shown by Keys, Pope, and Pope (2016) in the case of the United States, and by Andersen et al. (2017) for Denmark. These issues were discussed in detail in a 2015 conference on "Mortgage Contract Design: Implications for Households, Monetary Policy, and Financial Stability" held at the Federal Reserve Bank of New York. The conference agenda and presentation slides are available at https:// www.newyorkfed.org/research/conference/2015/mortgage_design.html.

${ }^{25}$ Bankruptcy and limits on recourse for secured debt represent implicit forms of insurance because they provide options for some borrowers to repay less than the outstanding face value of their debt in situations where they have experienced negative shocks to their net wealth. See Livshits, MacGee, and Tertilt (2007), Gross and Notowidigdo (2011), and Feibelman (2005) for further discussion and evidence on the role of bankruptcy as a form of social insurance. 


\section{REFERENCES}

Agarwal, S., G. Amromin, S. Chomsisengphet, T. Landvoigt, T. Piskorski, A. Seru, and V. Yao. 2017.

"Mortgage Refinancing, Consumer Spending, and Competition: Evidence from the Home Affordable Refinancing Program.” NBER Working Paper no. 21512.

Amromin, G., and C. Kearns. 2014. "Access to Refinancing and Mortgage Interest Rates: HARPing on the Importance of Competition." Federal Reserve Bank of Chicago Working Paper no. 2014-25, December.

Andersen, S., J. Campbell, K. Nielsen, and T. Ramadorai. 2017. "Sources of Inaction in Household Finance: Evidence from the Danish Mortgage Market." Working paper. https://papers.ssrn.com/sol3/papers .cfm?abstract_id $=2463575$

Ashcraft, A., M. Bech, and S. Frame. 2010. "The Federal Home Loan Bank System: The Lender of Next-to-Last Resort?” Journal of Money, Credit, ANd Banking 42: 551-83. doi:10.1111/j.1538-4616.2010.00299.x.

Barth, J. R. 1991. The Great Savings and Loan Debacle. Washington, D.C.: American Enterprise Institute Press.

Beraja, M., A. Fuster, E. Hurst, and J. Vavra. 2018. "Regional Heterogeneity and Monetary Policy." Federal Reserve Bank of New York Staff Reports, no. 731, March.

Berg, J., and M. B. Nielsen. 2014. "A New Housing Finance System for the U.S.? Lessons from the Danish Model." In J. Colombano and A. Shah, eds., LeArning from the WorLD. London: Palgrave Macmillan.

Bernanke, B. 2009. "The Future of Mortgage Finance in the United States." B.E. Journal of Economic Analysis And Policy 9, no. 3, Symposium, Article 2. doi:10.2202/1935-1682.2225.

Brown, J. R., and A. Finkelstein. 2008. "The Interaction of Public and Private Insurance: Medicaid and the Long-Term Care Insurance Market.” American Economic Review 98, no. 3: 1083-102. doi: 10.1257/aer.98.3.1083.

Campbell, J. 2013. “Mortgage Market Design.” Review of Finance 17, no. 1:1-33.

Demiroglu, C., and C. James. 2012. "How Important Is Having Skin in the Game? Originator-Sponsor Affiliation and Losses on Mortgage-Backed Securities." Review of Financial Studies 25, no. 11 (November): 3217-58.

Djankov, S., C. McLiesh, and A. Shleifer. 2007. "Private Credit in 129 Countries." Journal of FinanCial ECONOMICs 12, no. 2: 77-99.

Eberly, J., and A. Krishnamurthy. 2014. "Efficient Credit Policies in a Housing Debt Crisis." Brookings Papers on Economic Activity, Fall. https://www.brookings.edu/wp-content/ uploads/2016/07/fall2014bpea_eberly_krishnamurthy.pdf. 


\section{REFERENCES (Continued)}

Federal Housing Finance Agency. 2017. "FHFA Announces Modifications to High LTV Streamlined Refinance Program and Extension of HARP through December 2018." Press release, August 17.

Feibelman, A. 2005. "Defining the Social Insurance Function of Consumer Bankruptcy." American Bankruptcy Institute LaW Review 13: 129.

Ferreira, F., J. Gyourko, and J. Tracy. 2010. "Housing Busts and Household Mobility." Journal of Urban Economics 68, no. 1 (July): 34-45. https://doi.org/10.1016/j.jue.2009.10.007.

Finkelstein, D., A. Strzodka, and J. Vickery. 2018. "Credit Risk Transfer and De Facto GSE Reform." Federal Reserve Bank of New York Economic Policy Review 24, no. 3 (December): 88-116.

Frame, W. S., A. Fuster, J. Tracy, and J. Vickery. 2015. "The Rescue of Fannie Mae and Freddie Mac." Journal of Economic Perspectives 29, no. 2: 25-52. https://doi.org/10.1257/jep.29.2.25.

Freddie Mac. 2017. "Relief Refinance." Bulletin to Freddie Mac Loan Sellers. September 8. http://www.freddiemac.com/singlefamily/guide/bulletins/pdf/bll1717.pdf.

Frankel, A. B., J. Gyntelberg, K. Kjeldsen, and M. Persson. 2004. “The Danish Mortgage Market.” BIS Quarterly Review, March.

Fuster, A., and J. Vickery. 2015. "Securitization and the Fixed-Rate Mortgage." Review of Financial Studies 28, no. 1: 176-211.

Ghent, A. C., and M. Kudlyak. 2011. "Recourse and Residential Mortgage Default: Evidence from U.S. States.” Review of Financial Studies 24, no. 9: 3139-86. https://doi.org/10.1093/rfs/hhr055.

Green, R. K., and S. M. Wachter. 2005. “The American Mortgage in Historical and International Context.” Journal of Economic Perspectives 19, no. 4: 93-114.

Gross, T., and M. J. Notowidigdo. 2011. "Health Insurance and the Consumer Bankruptcy Decision: Evidence from Expansions of Medicaid." Journal of Public Economics 95, no. 7-8: 767-78. https://doi.org/10.1016/j.jpubeco.2011.01.012.

Guttentag, J. 2010. “Are Mortgage Assumptions a Good Deal?” Mortgage Professor (blog), July 12. https://www.mtgprofessor.com/a\%20-\%20options/are_assumptions_a_good_deal.htm.

Hsu, J. W., D. A. Matsa, and B. Melzer. Forthcoming. "Unemployment Insurance as a Housing Market Stabilizer." American Economic Review. https://ssrn.com/abstract=2185198 or http://dx.doi.org/ $10.2139 /$ ssrn.2185198. 


\section{REFERENCES (CONTINUED)}

International Monetary Fund. 2000. "Asset Prices and the Business Cycle." IMF WorLd Economic Outıоoк, May.

Kalotay, A. 2015. "The Case for the Ratchet Mortgage." Presentation at the Federal Reserve Bank of New York Conference on Mortgage Contract Design: Implications for Households, Monetary Policy, and Financial Stability, May 20-21. https://www.newyorkfed.org/medialibrary/media/research/ conference/2015/mortgage_design/kalotay.pdf.

Kane, E. J. 1989. The S\&L Insurance Mess: How Did It Happen? Washington, D.C.: Urban Institute Press.

Keys, B., D. G. Pope, and J. C. Pope. 2016. "Failure to Refinance." Journal of Financial Economics 122, no. 3: 482-99.

Lea, M. 2010. "International Comparison of Mortgage Product Offerings." Research Institute for Housing America, white paper.

Livshits, I., J. MacGee, and M. Tertilt. 2007. "Consumer Bankruptcy: A Fresh Start." AmERICAN ECONOMic Review 97, no. 1: 402-18.

Meuli, J., T. Nellen, and T. Nitschka. 2017. "Securitization, Loan Growth, and Bank Funding: The Swiss Experience Since 1932." Swiss National Bank Working Paper.

Møller, M., and N. C. Nielsen. 1997. "Dansk Realkredit Gennem 200 År.” (“Danish Mortgage Financing through 200 Years"). BRFKREDIT.

Passmore, W. 2005. "The GSE Implicit Subsidy and the Value of Government Ambiguity." Real Estate ECONOMICs 33: 465-86. doi:10.1111/j.1540-6229.2005.00126.x.

Quigley, J. 1987. "Interest Rate Variations, Mortgage Prepayments, and Household Mobility." Review of ECONOMics AND Statistics 69, no. 4: 636-43. doi: 10.2307/1935958.

Vickery, J., and J. Wright. 2013. "TBA Trading and Liquidity in the Agency MBS Market." Federal Reserve Bank of New York Economic Policy Review 19, no. 1 (May): 1-18.

White, M. J. 2007. "Bankruptcy Reform and Credit Cards." Journal of Economic Perspectives 21, no. 4: 175-200.

Willen, P. 2014. "Mandated Risk Retention in Mortgage Securitization: An Economist's View." American ECONOMIC Review 104, no. 5: 82-7. doi: 10.1257/aer.104.5.82.

The Economic Policy Review is published by the Research and Statistics Group of the Federal Reserve Bank of New York. The views expressed are those of the individual authors and do not necessarily reflect the position of the Federal Reserve Bank of New York or the Federal Reserve System. Economic Policy Review articles may be reproduced for educational or training purposes, provided they are reprinted in full; include credit to the author(s), the publication, and the Bank; and include the publication's disclaimer. (c) 2018 The Federal Reserve Bank of New York 